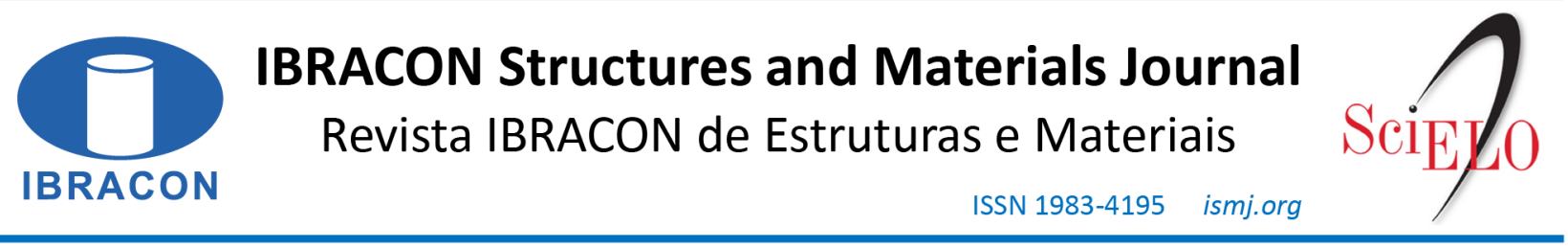

ORIGINAL ARTICLE

\title{
Numerical and parametric study of the yield stress limits of reinforcement bars in clay block masonry structures
}

\section{Estudo numérico e paramétrico sobre o limite da tensão de escoamento da armadura na alvenaria estrutural de blocos cerâmicos}

\author{
Orieta Soto Izquierdo ${ }^{\mathrm{a}}$ \\ Márcio Roberto Silva Corrêa ${ }^{\mathrm{b}}$ (D) \\ Indara Soto Izquierdo ${ }^{\mathrm{a}}$ (D) \\ Iván Gómez Araújo ${ }^{c}$
}

\begin{abstract}
${ }^{a}$ Universidade Federal do Tocantins - UFT, Curso de Engenharia Civil, Palmas, TO, Brasil
bUniversidade de São Paulo - USP, Departamento de Estruturas, São Carlos, SP, Brasil

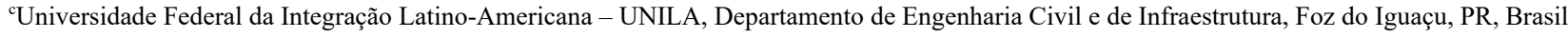

Received 07 June 2020

Accepted 05 April 2021

\begin{abstract}
The Brazilian Standard Structural Masonry considers for the maximum tensile stress $\left(f_{s}\right)$ of the reinforcements embedded in the grout in clay blocks with smooth surfaces several limits of the yield stress for the reinforcement $\left(\mathrm{f}_{\mathrm{yk}}\right)$. This work aims to analyze the limits of the yield stress of reinforcement bars in clay block masonry structures by numerical and parametric analysis in push-out and pull-out tests, varying the type of grout and reinforcement diameter. A numerical study was performed using a 3D-model with the DIANA ${ }^{\circledR}$ software based on the Finite Element Method. The parametric study confirmed that the limits obtained in this research for reinforcement diameter of $8 \mathrm{~mm}, 10 \mathrm{~mm}, 12.5 \mathrm{~mm}$ and $16 \mathrm{~mm}$ are in agreement with the limits specified by the Brazilian Standard, with exception of the $20 \mathrm{~mm}$ diameter, which limit was lower than indicated by the Standard. The tensile stress limits of the embedded reinforcement progressively reduce with increasing rebar diameter, being the failure is dominated by the bond strength of the block/grout interface.
\end{abstract}

Keywords: yield stress, bond strength, block/grout interface, finite element, clay blocks.

Resumo: A norma brasileira de alvenaria estrutural considera para a tensão máxima de tração das armaduras $\left(\mathrm{f}_{\mathrm{s}}\right)$ embutida no graute em blocos cerâmicos com superfícies lisas vários limites da tensão de escoamento do aço $\left(\mathrm{f}_{\mathrm{yk}}\right)$. Este trabalho teve como principal objetivo analisar os limites da tensão de escoamento das armaduras inseridas na alvenaria estrutural de blocos cerâmicos por meio de análises numéricas e paramétricas em corpos de provas push-out e pull-out, variando o tipo de graute e diâmetro das armaduras. O estudo numérico dos modelos analisados foi feito pelo Método dos Elementos Finitos utilizando o pacote computacional FX+DIANA ${ }^{\circledR}$. A análise paramétrica confirmou que os limites obtidos nesta pesquisa para armaduras com diâmetros de $8 \mathrm{~mm}, 10 \mathrm{~mm}, 12.5 \mathrm{~mm}$ e $16 \mathrm{~mm}$ estão em concordância com os especificados pela norma brasileira, com exceção da armadura de $20 \mathrm{~mm}$ de diâmetro, cujo limite ficou menor que o apontado pela norma. Dessa maneira, a tensão de escoamento da armadura embebida no graute diminui progressivamente com o aumento do diâmetro das barras, sendo a falha dominada pela tensão de aderência da interface que se cria entre as paredes dos blocos cerâmicos e o graute.

Palavras-chave: tensão de escoamento, tensão de aderência, interface bloco/graute, elementos finitos, blocos cerâmicos.

How to cite: O. Soto Izquierdo, M. R. S. Corrêa, I. Soto Izquierdo, and I. G. Araújo, "Numerical and parametric study of the yield stress limits of reinforcement bars in clay block masonry structures," Rev. IBRACON Estrut. Mater., vol. 14, no. 6, e14611, 2021, https://doi.org/10.1590/S198341952021000600011

Corresponding author: Orieta Soto Izquierdo. E-mail: orietasi@uft.edu.br

Financial support: The authors would like to thank the Conselho Nacional de Desenvolvimento Científico e Tecnológico-CNPq for the financial support. Conflict of interest: Nothing to declare. 


\section{INTRODUCTION}

Structural masonry is an important structural system that has significantly evolved over the years. Buildings have become increasingly tall, reaching 20 floors. Furthermore, the taller the building, the larger the compression levels and vertical loads that are attributed to wind action and torsion. In structural masonry, compression is usually resisted by filling the vertical holes with grout (liquid concrete with small aggregate), which increases the resistance of the masonry to compression [1].

With respect to traction on the walls, reinforcement bars that are properly coated with grout are generally used to solidify the compound because the resistance of masonry is low. Reinforcements are a solution to increase the tensile strength and thus improve the mechanical behavior of masonry under lateral loading [2].

When a wall is subjected to lateral action, one of its sides is compressed, whereas the other is subjected to traction. Under these conditions, internal tensions are observed on the grout/block interfaces because of the different deformation properties. By analyzing the internal components of the grout/block contact plane, it can be concluded that rupture is caused by slippage near the plane [3].

Soric and Tulin [4] concluded that two types of bond should be considered when evaluating the performance of reinforced masonry: the bond between reinforcing steel and grout, and the bond between the grout and internal faces of the concrete unit. The bond that can be developed between the reinforcement and surrounding grout is a complex phenomenon that is dominated by the interlocking action of the reinforcing bar ribs in the grout mass. However, the bond between the grout and surrounding masonry unit is primarily limited by the adhesion with the interface.

\subsection{Justification}

Regarding the tension on the walls, because of the low resistance of masonry, reinforcement bars that are properly coated with grout are generally used to solidify the whole structure. International reference standards, such as British BS 5628-2 [5], European EC6-1 [6] and Australian AS 3700 [7], present an indirect limit for the maximum reinforcement diameter embedded in a grouted hole. However, the Brazilian Standard of Structural Masonry ABNT NBR 16868-1 [8] imposes limits directly for the maximum tensile stress $\left(\mathrm{f}_{\mathrm{s}}\right)$ of the reinforcements and maximum reinforcement rate in a grouted hole.

The Brazilian Standard of Structural Masonry ABNT NBR 16868-1 [8] suggests that in clay blocks whit smooth surface the maximum tensile stress of the reinforcement embedded in the grout cannot be larger than the yield stress $\left(f_{\mathrm{yk}}\right)$ for $10 \mathrm{~mm}$ rebar diameters, $75 \%$ of its yield stress $\left(0.75 \mathrm{f}_{\mathrm{yk}}\right)$ for $12.5 \mathrm{~mm}$ rebar diameters and $50 \%$ of its yield stress $\left(0.5 \mathrm{f}_{\mathrm{yk}}\right)$ for $16 \mathrm{~mm}$ or more rebar diameters. This request is relevant for high rise buildings and for buildings in high-intensity seismic zones. Therefore, the present study is mainly to verify the need to establish such limits.

A better understanding of the behavior of structural masonry requires research on the block/grout interface, especially considering that wind loads become substantial for tall buildings causing significant traction on the bracing walls.

Sipp [9] studied the properties that affect the adherence between 5 types of ceramic blocks and two types of grouts. The push-out test was used to evaluate the bond strength mobilized by the combination of these different materials. In addition, the pull-out test was also employed for some block types, seeking a more realistic analysis of the bonding behavior on masonry elements. The results obtained in the push-out test prove that there is a wide variation in the results, depending on the type of block and grout employed. Some of the main characteristics that influenced these results were the shape of the block cells and the shrinkage of the grout. In the case of grout, the use of grout with higher compression resistance was responsible for the reduction in the results of the push test, precisely due to the reduction in the contact area caused by the shrinkage of the filler material.

Guarnieri [10] analyzed the influence of the structural ceramic block/grout adhesion on the mechanical behavior of the assembly in order to determine a value of adhesion tension. The author concluded that the grout/ceramic block adhesion is superior to the mechanical tensile strength of the ceramic block and, therefore, the rupture of the assembly will occur first in the block.

In this regard, Izquierdo et al. [11] studied the behavior of the block/grout interface of concrete and clay block masonry. Their study concluded that there is a good bond between the internal faces of the concrete blocks and grout, enough to prevent infill-slippage, and that the whole tensile strength of the usual reinforcement bars is achieved provided they are properly anchored. Nevertheless, for clay blocks, there is low bond between the interface of the clay blocks and grout, allowing for infill-slippage before the reinforcement bars reach their yield stress. In this way, numerical modeling of masonry structures can effectively be useful for better understanding of the mechanical behavior of masonry elements for scenarios different from those tested in the laboratory [2]. Therefore, this paper aims to 
investigate the block/grout interface in clay blocks and verify the limits on the yield stress of the reinforcement by performing experimental and numerical tests, thereby enabling a parametric analysis. This study intends to draw the attention of technologists to the importance of ensuring the homogeneity of masonry by considering the bond to be a study parameter of the grout.

\section{EXPERIMENTAL INVESTIGATION}

This experimental investigation studied the masonry behavior using push-out specimens to determine the bond strength between the grout and clay unit, and pull-out specimens to study the behavior of the interface of the grout/block/reinforcement set. One type of block material (clay), two types of grout (large and small compressive resistance) and two rebar diameters $(12.5 \mathrm{~mm}$ and $16 \mathrm{~mm})$ were considered.

These laboratory tests were preceded by a set of material characterization tests. Statistical tests (Student's t test) were applied to evaluate the differences of the experimental results at a 5\% significance level, for a better understanding of the results.

A detailed description of the experimental results was presented by Izquierdo et al. [11]. Figure 1 and Figure 2 show the nominal dimensions and test rig of the push-out and pull-out specimens, respectively. The experimental tests were carried out on servo-hydraulic universal machine INSTRON brand, model 8506, and the reading of the data was done with SYSTEM 5000 acquisition system.

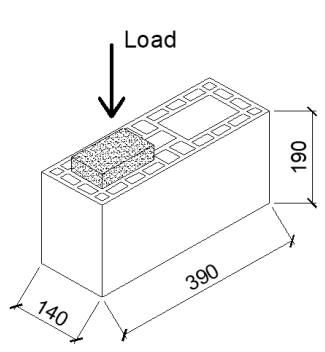

(a)

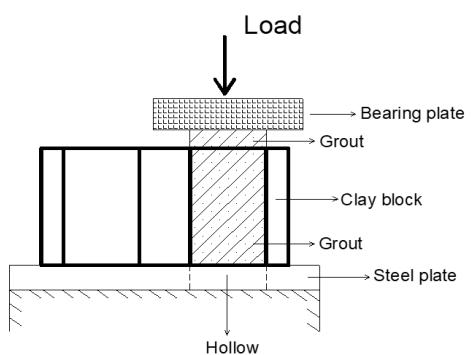

(b)

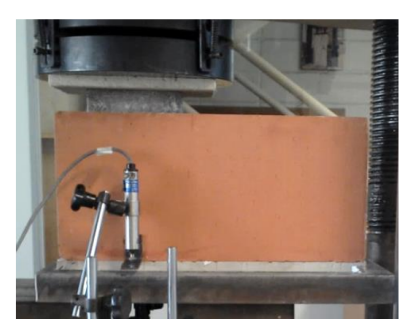

(c)

Figure 1. Push-out specimens: (a) Nominal dimensions [in mm], (b) test rig and (c) experimental test (Adapted from Izquierdo et al. [11]).

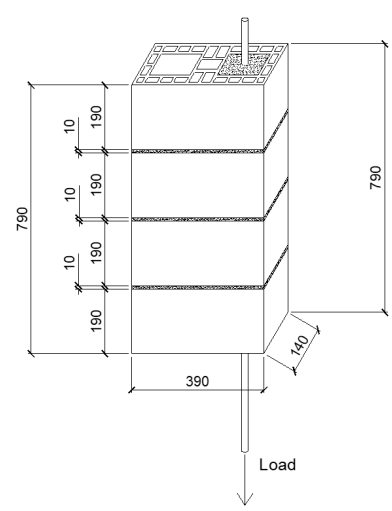

(a)

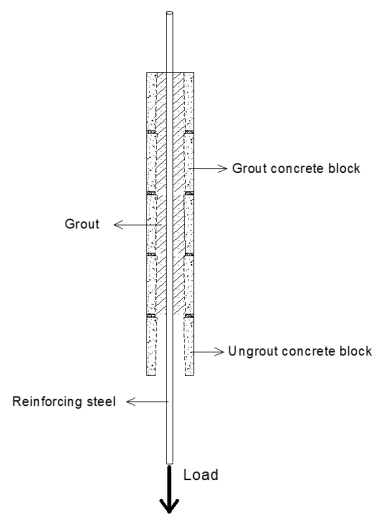

(b)

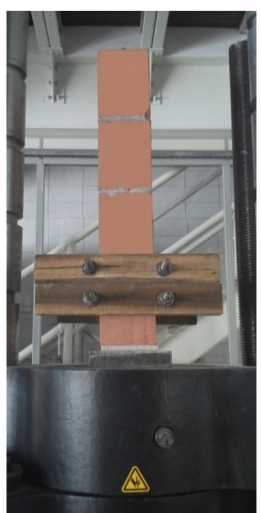

(c)

Figure 2. Pull-out specimens: (a) Nominal dimensions [in mm], (b) test rig and (c) experimental test (Adapted from Izquierdo et al. [11]).

Two series were built with six specimens for each series for the push-out test:

- Series ClG14: Clay block and grout G14

- Series ClG30: Clay block and grout G30 
Four series were built with six specimens for each series for the push-out test:

- Series ClG14S12: Clay block, grout G14 and rebar diameters $12.5 \mathrm{~mm}$

- Series ClG30S12: Clay block, grout G30 and rebar diameters $12.5 \mathrm{~mm}$

- Series ClG14S16: Clay block, grout G14 and rebar diameters $16 \mathrm{~mm}$

- Series ClG30S16: Clay block, grout G30 and rebar diameters $16 \mathrm{~mm}$

Complementary tests were performed to characterize the masonry: compressive strength testing of cylindrical mortar specimens, cylindrical grout specimens, and units. The specimens were rectified to obtain regular and smooth surfaces.

The mean of the compressive strength for grout G14 and G30 used for filling the clay blocks was $14.18 \mathrm{MPa}$ and 31.43 MPa, respectively. Grout G14 was designed to be weaker than grout G30.

The reinforcement rebars were subjected to tensile strength tests. Three $12.5 \mathrm{~mm}$ and $16 \mathrm{~mm}$ steel rebar samples were submitted to direct tensile tests. Table 1 shows the results obtained on the reinforcements used in clay blocks. The yield stress was calculated according to ABNT NBR 6892-1 [12].

Table 1. Results of the steel reinforcements $\varnothing 12.5 \mathrm{~mm}$ and $\varnothing 16 \mathrm{~mm}$ used in clay blocks.

\begin{tabular}{|c|c|c|c|c|c|c|}
\hline $\begin{array}{c}\text { Diameter } \\
\text { rebar }(\mathrm{mm})\end{array}$ & $\begin{array}{c}\text { Area of } \\
\text { reinforcement } \\
\text { cross section }\left(\mathrm{mm}^{2}\right)\end{array}$ & & $\begin{array}{l}\text { Mean Ultimate } \\
\text { Load }(\mathbf{k N})\end{array}$ & $\begin{array}{l}\text { Mean Yield } \\
\text { Load }(\mathbf{k N})\end{array}$ & $\begin{array}{c}\text { Mean Ultimate } \\
\text { Stress (MPa) }\end{array}$ & $\begin{array}{c}\text { Mean Yield } \\
\text { Stress (MPa) }\end{array}$ \\
\hline \multirow{3}{*}{12.5} & \multirow{3}{*}{125} & & 93.32 & 65.55 & 760.43 & 534.15 \\
\hline & & S.D & 1.30 & 1.94 & 10.58 & 15.77 \\
\hline & & C.V (\%) & 1.39 & 2.95 & 1.39 & 2.95 \\
\hline \multirow{3}{*}{16} & \multirow{3}{*}{200} & & 159.86 & 117.32 & 795.05 & 583.52 \\
\hline & & S.D & 1.91 & 3.28 & 9.52 & 16.30 \\
\hline & & C.V $(\%)$ & 1.20 & 2.79 & 1.20 & 2.79 \\
\hline
\end{tabular}

S.D: Standard Deviation. C.V: Coefficient of Variation

The bond strength was determined by dividing the maximum load applied by the area of the internal cavity surface of the unit. The average value of this area was $0,072 \mathrm{~m}^{2}$. The results of the push-out tests are displayed in Table 2 .

Table 2. Results of the push-out tests [11].

\begin{tabular}{ccccccc}
\hline Series & $\begin{array}{c}\text { Mean Ultimate Load } \\
(\mathbf{k N})\end{array}$ & S.D & C.V (\%) & Bond Strength (MPa) & S.D & C.V (\%) \\
\hline ClG14 & 11.64 & 1.32 & 11.31 & 0.16 & 0.02 & 8.87 \\
\hline ClG30 & 14.02 & 1.24 & 8.87 & 0.19 & 0.02 & 8.87 \\
\hline
\end{tabular}

S.D: Standard Deviation. C.V: Coefficient of Variation

Table 3 shows the maximum stress of the pull-out clay block specimens for the four series. Figure 3 presents the results of the pull-out loads and the reference values of the yield load and the ultimate load, both obtained in the simple tensile test of the rebars, according to Izquierdo et al. [11].

Table 3. Results of the pull-out of clay block specimens [11].

\begin{tabular}{ccccccc}
\hline Series & Mean Ultimate Load (kN) & S.D & C.V (\%) & $\begin{array}{c}\text { Mean Ultimate Stress } \\
\text { (MPa) }\end{array}$ & S.D & C.V (\%) \\
\hline ClG14S12 & 48.47 & 1.14 & 2.36 & 394.95 & 9.31 & 2.36 \\
\hline ClG30S12 & 59.26 & 7.42 & 10.51 & 482.91 & 50.75 & 10.51 \\
\hline ClG14S16 & 48.96 & 1.76 & 3.60 & 243.49 & 8.76 & 3.60 \\
\hline ClG30S16 & 60.11 & 5.11 & 8.50 & 298.94 & 25.40 & 8.50 \\
\hline
\end{tabular}

S.D: Standard Deviation. C.V: Coefficient of Variation 


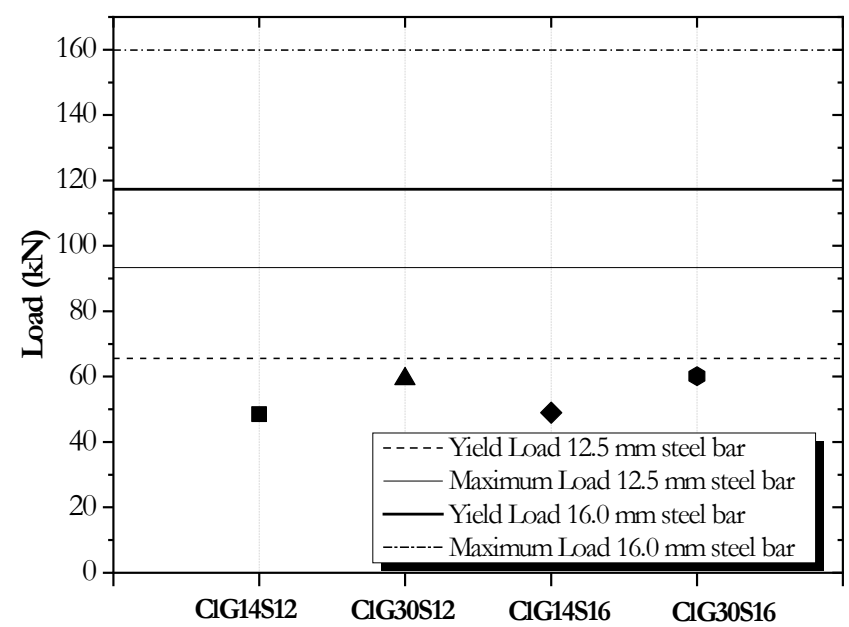

Figure 3. Results of the pull-out of clay block specimens with yield load and maximum load of the reinforcements [11].

The pull-out specimens built with reinforcement of $12.5 \mathrm{~mm}$ and $16 \mathrm{~mm}$ diameter reached an ultimate load less than the yield load of the referred bar. The maximum load of the specimens with the same type of grout obtained similar values. The Figure 3 shows that the failure of the pull-out specimens was determined by the type of grout.

Izquierdo et al. [11] concluded that the bond load between the grout and clay block was $11.64 \mathrm{kN}$ for grout G14 and $14.02 \mathrm{kN}$ for grout G30, for a single grouting block. These loads multiplied by the number of grouting blocks used in the pull-out specimens (4 blocks) set important limits related to the grout/block bond. These values can be compared with the ultimate loads obtained in the pull-out tests, as shown in Table 4.

Table 4. Load limited by bond and ultimate load of the pull-out tests of clay blocks [11].

\begin{tabular}{ccccccc}
\hline \multicolumn{2}{c}{ Push-out specimens } & & \multicolumn{3}{c}{ Pull-out specimens } \\
\cline { 1 - 4 } \cline { 5 - 7 } Ultimate Load $\mathbf{4} \mathbf{4}(\mathbf{k N})$ & \multicolumn{4}{c}{ Ultimate Load (kN) } \\
\hline G14 & G30 & ClG14S12 & ClG14S16 & ClG30S12 & ClG30S16 \\
\hline 46.56 & 56.12 & 48.49 & 48.96 & 59.26 & 60.10 \\
\hline
\end{tabular}

The results in Table 4 show that the ultimate loads of pull-out tests were approximately equal to the extrapolated limits of the push-out tests. The statistical analysis showed that these limits are not significantly different. Therefore, the pull-out specimens breached before the reinforcement bars reached its yield strength.

\section{NUMERICAL MODEL}

The numerical model applied to the study of the block/grout interface in the clay block masonry structures was defined using the Fx + DIANA ${ }^{\circledR}$ software program [13].

The numerical analysis was performed by two steps. In the first step, the validation of the numerical model was carried out based on the experimental results. The second step included a parametric analysis varying the rebar diameters on the pull-out specimens $(8 \mathrm{~mm}, 10 \mathrm{~mm}$ and $20 \mathrm{~mm}$ ).

The simplified micro-model was using in this study. Some researchers adopted micro-modeling approaches to study masonry as they represent its comp lex behavior very well. Mortar and two unit-mortar interfaces are lumped into a zero-thickness joint (modeled using an interface element) between expanded masonry units [2], [14], [15].

The Quasi-Newton iteration method (Secant) and a displacement convergence norm was used in the DIANA ${ }^{\circledR}$ software to solve the three-dimensional finite element model adopted in the push-out and pull-out specimens.

\subsection{Finite Element Mesh}

The mesh was composed of a HX24L solid element to represent the masonry units, grout and a TP18L solid element to represent the steel reinforcement (Figure 4). A Q24IF interface element was employed to represent the block/grout interface, grout/reinforcement interface and bed joints. The Q24IF element is an interface element between two planes 
in a three-dimensional configuration (Figure 5), suitable for three-dimensional models. Each node of this element has three degrees of freedom and the element is based on linear interpolation and Gaussian integration.

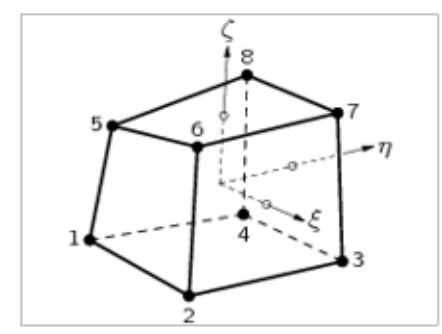

(a)

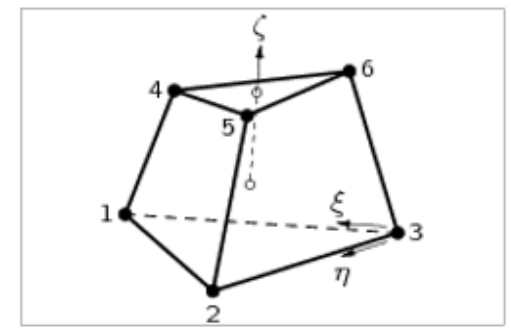

(b)

Figure 4. (a) HX24L solid element of the units and grout and (b) TP18L solid element of the steel reinforcement used in the numerical modeling [13].

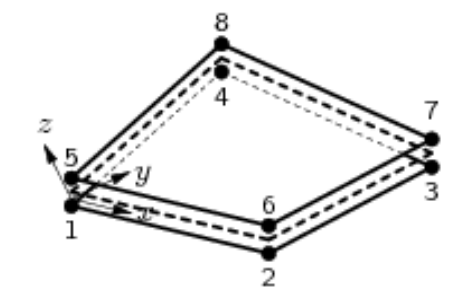

(a) Topologia

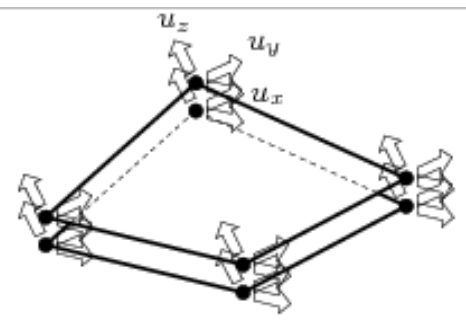

(b) Deslocamentos

Figure 5. Q24IF interface element [13].

The mesh convergence was done satisfactorily with three different refinement levels to evaluate its influence on the results. Table 5 and Table 6 show the number and size elements of the final mesh of the push-out tests and pull-out test, respectively.

Table 5. Number and size elements of the push-out mesh.

\begin{tabular}{|c|c|c|c|}
\hline & Clay block & Grout & Block/grout interface \\
\hline Elements number & 1260 & 462 & 180 \\
\hline Size of elements (mm) & $10 \times 10 \times 40$ & $10 \times 10 \times 40$ & $40 \times 10$ \\
\hline Subtotal & & & 180 \\
\hline Total & & 1902 & \\
\hline
\end{tabular}

Table 6. Number and size elements of the pull-out mesh.

\begin{tabular}{|c|c|c|c|c|c|c|}
\hline & Clay block & Grout & Reinforcement & $\begin{array}{c}\text { Block/grout } \\
\text { interface }\end{array}$ & $\begin{array}{c}\text { Grout/reinforcement } \\
\text { interface } \\
\end{array}$ & $\begin{array}{c}\text { Bed joints } \\
\text { masonry }\end{array}$ \\
\hline $\begin{array}{l}\text { Elements } \\
\text { number }\end{array}$ & 5040 & 1848 & 500 & 720 & 180 & 252 \\
\hline $\begin{array}{l}\text { Size of } \\
\text { elements } \\
(\mathrm{mm})\end{array}$ & $10 \times 10 \times 40$ & $10 \times 10 \times 40$ & $10 \times 10 \times 200$ & $40 \times 10$ & $10 \times 200$ & $10 \times 10$ \\
\hline Subtotal & & 7388 & & & 1152 & \\
\hline Total & & & & 8540 & & \\
\hline
\end{tabular}




\subsection{Loading and Boundary Conditions}

The push-out specimens consisted of a single clay block with one of its cavities completely grouted. The salient grout from the surface of the block at a distance of $30 \mathrm{~mm}$ was loaded in compression through a bearing plate at the top surface, while the block was supported only around the perimeter of the unit shells at the bottom surface. The pull-out specimens were built with four clay blocks in stack bond. The 4 blocks were grouted. The reinforcement rebar was subjected to a tensile load [11].

Similarly to the experimental tests (see Figure $1 \mathrm{c}$ and Figure 2c), the boundary conditions used in the push-out and pull-out specimens were restrictions of the displacements in the $\mathrm{Z}$ direction at half of the nodes of the bottom block. Two nodes of the symmetry axis were restricted in the $\mathrm{X}, \mathrm{Y}$, and $\mathrm{Z}$ directions to avoid numerical instability.

In the case of the push-out specimens, vertical displacements were imposed on all nodes of the top of the grout (Figure 6a), and in the case of the pull-out specimens, vertical displacements were imposed on all nodes of the base of the reinforcement rebar (Figure 6b). The boundary conditions and loading were similar in the experimental tests.

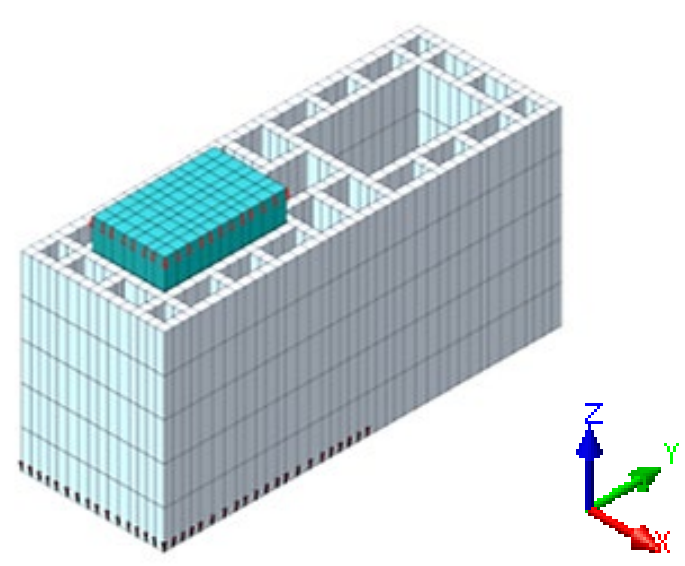

(a)

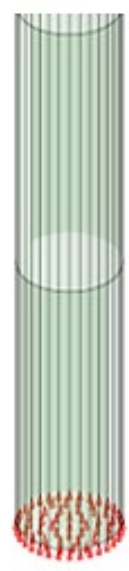

(b)

Figure 6. Vertical displacements of the (a) push-out and (b) pull-out specimens.

\subsection{Constitutive Models and Mechanical Properties}

Total Strain Crack Model was used to characterize the crack distribution and nonlinear behavior of both the units and grout. According to the DIANA ${ }^{\circledR}$ software [13], this model describes the tensile and compressive behavior of the material with one stress-strain relationship in a coordinate system that is fixed upon crack initiation. Exponential and parabolic constitutive laws were used to describe the tensile and compressive behavior of clay masonry units respectively, as shown in Figure $7 \mathrm{a}$ and Figure $7 \mathrm{~b}$. The shear behavior during cracking was described via a shear retention model defined by a constant, see Figure 7c [16].

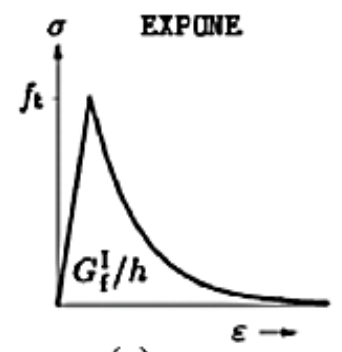

(a)

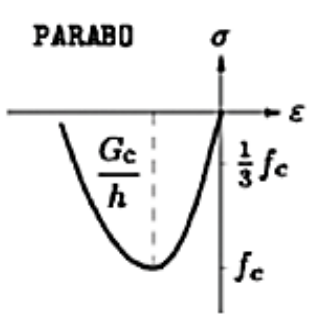

(b)

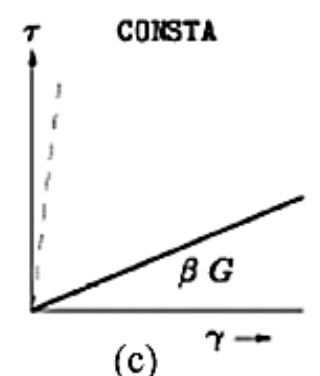

(c)

Figure 7. Mechanical behavior of the units used in numerical modeling: (a) tension, (b) compression, and (c) shear [13]. 
The mechanical properties are presented in Table 7 for masonry units and two types of grout and were determined during the characterization tests as presented by Izquierdo [11]. However, some properties that could not be obtained experimentally were calibrated by adjusting the numerical results with the experimental results. All mechanical properties units were considered in relation to its net area. The calibrated properties (indicated in the Table 7) were obtained according to Haach [16], Izquierdo [17], fib [18], Haach et al. [19], Diógenes [20] and Izquierdo [21].

Table 7. Mechanical properties of the Total Strain Crack Model (masonry units and grout).

\begin{tabular}{ccccc}
\hline Parameters & Symbol/Units & Clay block & Grout G14 & Grout G30 \\
\hline Elastic modulus (exp) & $\mathrm{E}(\mathrm{MPa})$ & 9876.43 & 20521.17 & 29719.67 \\
\hline Poisson (exp) & $v$ & 0.20 & 0.20 & 0.20 \\
\hline Tensile strength (exp) & $\mathrm{f}_{\mathrm{t}}(\mathrm{MPa})$ & 1.08 & 1.43 & 0.35 \\
\hline Fracture energy for Mode I (cal) & $\mathrm{G}_{\mathrm{fl}}(\mathrm{MPa} \cdot \mathrm{mm})$ & 0.06 & 0.03 & 0.06 \\
\hline $\begin{array}{c}\text { Compressive strength (exp) } \\
\text { Fracture energy under } \\
\text { compression (cal) }\end{array}$ & $\mathrm{f}_{\mathrm{c}}(\mathrm{MPa})$ & 30.92 & 3.18 & \multirow{2}{*}{5.57} \\
\hline Shear retention (cal) & $\beta$ & 5.51 & 0.5 & 0.5 \\
\hline
\end{tabular}

Experimental properties (exp). Calibrated properties (cal)

The model used for interface elements indicate that the block/grout interface and bed joints masonry was an interface cap model. This model was proposed by Lourenço and Rots [22], and further enhanced by Van Zijl [23] with modern plasticity concepts. This interface material model, also known as the "Composite Interface model" or "Cracking-Shearing-Crushing Model", is appropriate to simulate fracture, frictional slip, and crushing along material interfaces, which are possible failure modes of masonry interfaces. The model includes a tension cut-off model to capture Mode I failure, a Coulomb friction envelope to describe Mode II failure and a cap model for compressive failure (Figure 8) [2], [24], [25].

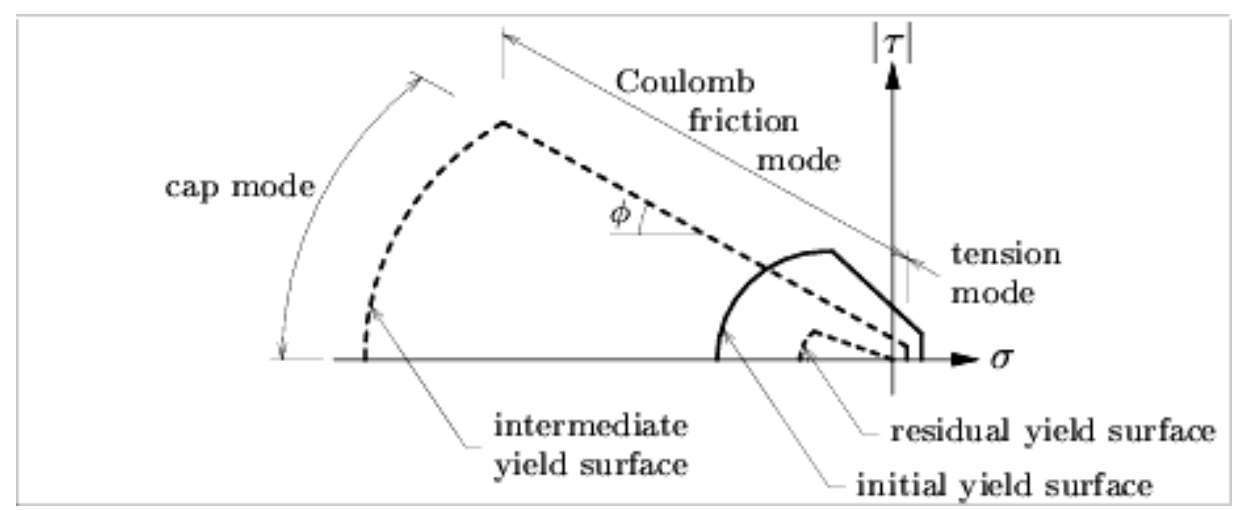

Figure 8. Constitutive model for masonry interfaces [22] adapted from Haach [16].

Table 8 shows the mechanical properties used for the Composite Interface Model of the block/grout interface and bed joints masonry. Most properties were obtained experimentally according to Izquierdo [17] and Oliveira [26]. Other properties (indicated in the Table 8) were obtained by calibrating the numerical and experimental model with similar raw material compositions based on previous work as Haach et al. [19], Oliveira [26], Capuzzo et al. [27] and Rahman and Ueda [28].

The normal stiffness $\left(\mathrm{k}_{\mathrm{n}}\right)$ was calculated based on the results of the direct tensile tests carried out to characterize the tensile bond strength of the unit-mortar. The shear stiffness $\left(\mathrm{k}_{\mathrm{t}}\right)$ was obtained through the results of the shear tests carried out on triplet specimens to characterize the shear behavior of clay unit-mortar interface interface [16], [19], [29].

Elasto-plastic behavior was adopted for the reinforcements through the yield criterion of the Von Mises model. These properties were obtained experimentally as presented by Izquierdo et al. [11]. Table 9 shows the mechanical properties used in this model. 
Table 8. Mechanical properties of the Composite Interface Model (block/grout interface and the bed joints masonry).

\begin{tabular}{|c|c|c|c|c|}
\hline Parameters & Symbol/Units & $\begin{array}{c}\text { Block/grout } \\
\text { interface }\end{array}$ & $\begin{array}{c}\text { Block/grout } \\
\text { interface }\end{array}$ & $\begin{array}{c}\text { Bed joints } \\
\text { masonry }\end{array}$ \\
\hline Normal stiffness (exp) & $\mathrm{k}_{\mathrm{n}}(\mathrm{MPa} / \mathrm{mm})$ & 1.00 & 1.00 & 11.71 \\
\hline Tangential stiffness (exp) & $\mathrm{k}_{\mathrm{t}}(\mathrm{MPa} / \mathrm{mm})$ & 1.76 & 1.19 & 11.71 \\
\hline Cohesion (exp) & fvo $(\mathrm{MPa})$ & 0.16 & 0.19 & 0.20 \\
\hline Friction coefficient (exp) & $\tan \varphi 0$ & 0.70 & 0.70 & 0.250 \\
\hline Dilatancy coefficient (exp) & $\tan \Psi$ & $1.00 \times 10^{-4}$ & $1.00 \times 10^{-4}$ & 1.723 \\
\hline Residual friction coefficient (exp) & $\tan \varphi_{\mathrm{r}}$ & 0.39 & 0.39 & 0.29 \\
\hline Confining normal stress (exp) & $\sigma_{u}(\mathrm{MPa})$ & -1.18 & -1.18 & -1.37 \\
\hline Exponential degradation coefficient (cal) & $\delta$ & 1.85 & 1.85 & 0 \\
\hline Tensile strength (exp) & $\mathrm{f}_{\mathrm{t}}(\mathrm{MPa})$ & 0.23 & 0.23 & 0.29 \\
\hline Fracture energy for Mode I (exp) & $\mathrm{G}_{\mathrm{fl}}(\mathrm{MPa} \cdot \mathrm{mm})$ & 0.02 & 0.02 & 0.02 \\
\hline Fracture energy for Mode II (exp) & $\mathrm{G}_{\mathrm{fII}}(\mathrm{MPa} \cdot \mathrm{mm})$ & 0.19 & 0.24 & 0.22 \\
\hline Cap critical compressive strength (exp) & $\mathrm{f}_{\mathrm{c}}(\mathrm{MPa})$ & 3.15 & 3.15 & 3.05 \\
\hline Shear traction control factor (cal) & $\mathrm{C}_{\mathrm{s}}$ & 4.00 & 4.00 & 4.00 \\
\hline Compressive fracture energy (cal) & $\mathrm{G}_{\mathrm{fc}}(\mathrm{MPa} \cdot \mathrm{mm})$ & 1.18 & 1.18 & 5.00 \\
\hline
\end{tabular}

Experimental properties (exp). Calibrated properties (cal)

Table 9. Mechanical properties used for the Von Mises model (reinforcement).

\begin{tabular}{cccc}
\hline Parameters & Symbol/Units & Ø 12.5 mm & Ø 16 mm \\
\hline Elastic modulus (exp) & E (MPa) & 198513.12 & 200844.39 \\
\hline Poisson (cal) & $v$ & 0.30 & 0.30 \\
\hline Yield stress (exp) & $\mathrm{f}_{\mathrm{y}}(\mathrm{MPa})$ & 556.24 & 588.60 \\
\hline
\end{tabular}

Experimental properties (exp). Calibrated properties (cal)

The grout/reinforcement interface was considered in the linear regime with $\mathrm{k}_{\mathrm{n}}=5 \mathrm{MPa} / \mathrm{mm}$ and $\mathrm{k}_{\mathrm{t}}=100 \mathrm{MPa} / \mathrm{mm}$.

\section{VALIDATION OF THE NUMERICAL MODEL}

The calibration of the numerical model was performed based on the comparison between the numerical and experimental results and failure modes.

\subsection{Push-Out Tests}

Figure 9 shows a comparison between the experimental and numerical behavior of the push-out tests corresponding to the $\mathrm{ClG} 14$ series and Figure 10 for the $\mathrm{ClG} 30$ series. Figure 11 displays the grout slippage of the numerical and physical models of the ClG14 series.

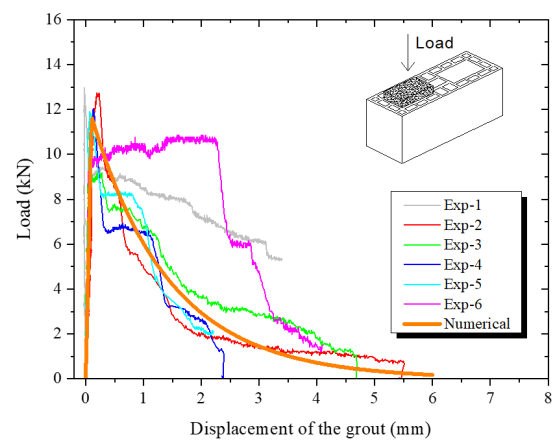

(a)

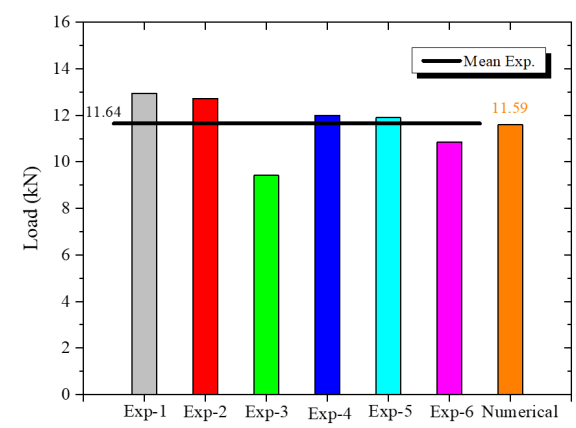

(b)

Figure 9. Validation of numerical results of the ClG14 series of push-out tests: (a) force $v s$ displacement diagrams and (b) mean maximum load. 


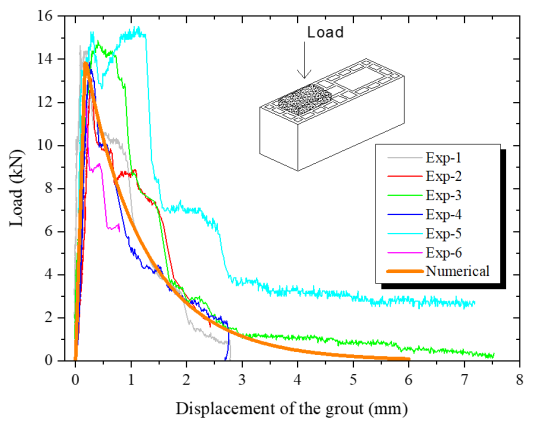

(a)

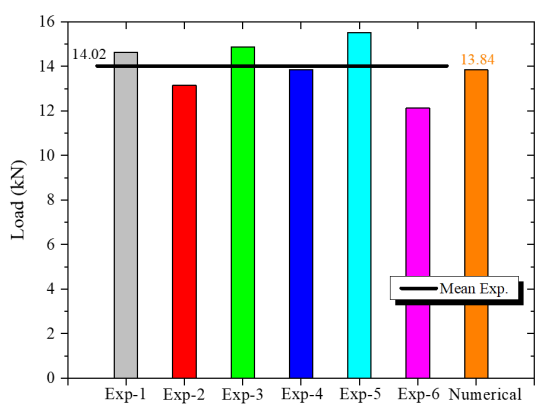

(b)

Figure 10. Validation of numerical results of the ClG30 series of push-out tests: (a) force vs displacement diagrams and (b) mean maximum load.

Figures 9 and 10 showed that the numerical model adequately predicts the same response of experimental push-out tests. The maximum difference between both models was less than $2 \%$. Therefore, it can be said that the numerical push-out model was calibrated.

Figure 11 shows that the numerical model characterizes the performance of the physical push-out model.

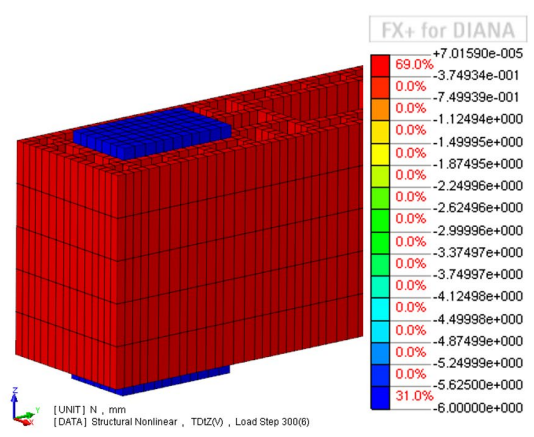

(a)

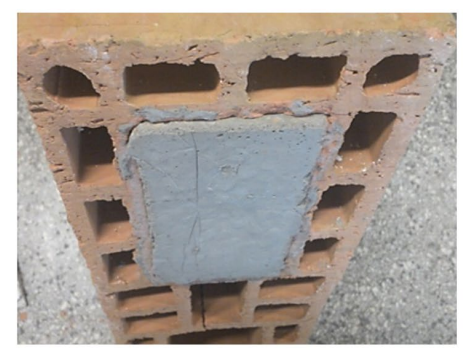

(b)

Figure 11. Displacement of the grout according to the ClG14 series (a) numerical model and (b) bottom face of the physical model.

\subsection{Pull-Out Tests}

Figure 12 to Figure 15 show a comparison of the experimental and numerical behavior of the pull-out tests for the ClG14S12, ClG14S16, ClG30S12 and ClG30S16 series, respectively.

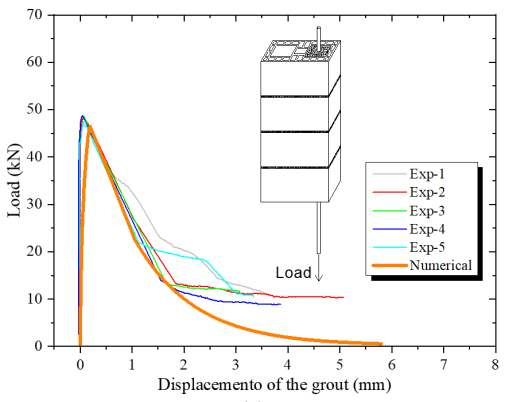

(a)

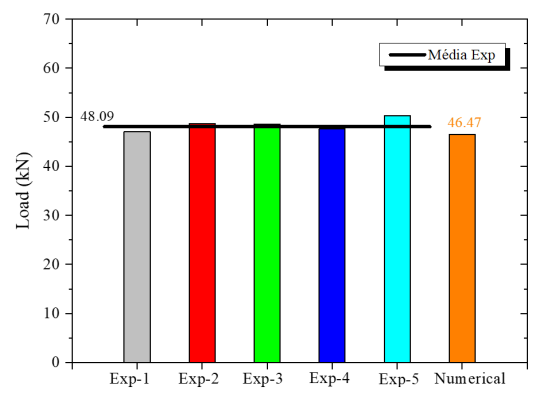

(b)

Figure 12. Validation of numerical results of the ClG14S12 series of pull-out tests: (a) force vs displacement diagrams and (b) mean maximum load. 


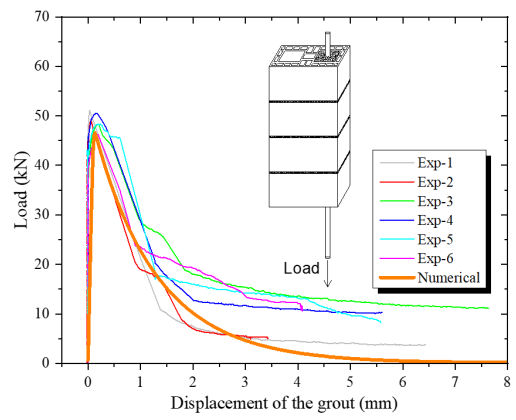

(a)

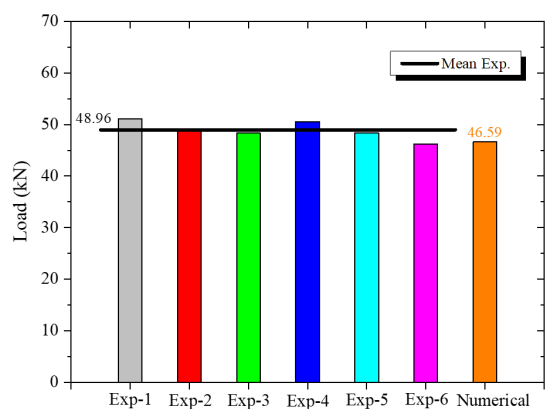

(b)

Figure 13. Validation of numerical results of the ClG14S16 series of pull-out tests: (a) force vs displacement diagrams and (b) mean maximum load.

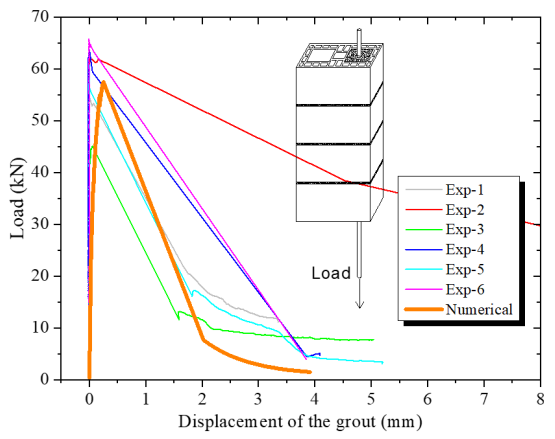

(a)

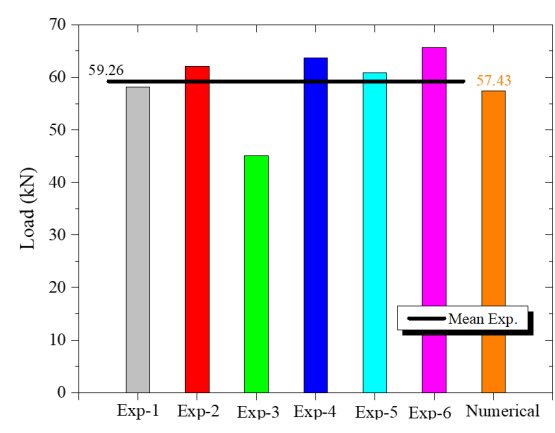

(b)

Figure 14. Validation of numerical results of the ClG30S12 series of pull-out tests: (a) force vs displacement diagrams and (b) mean maximum load.

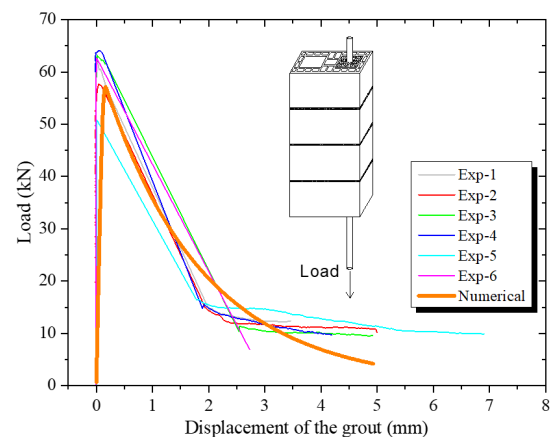

(a)

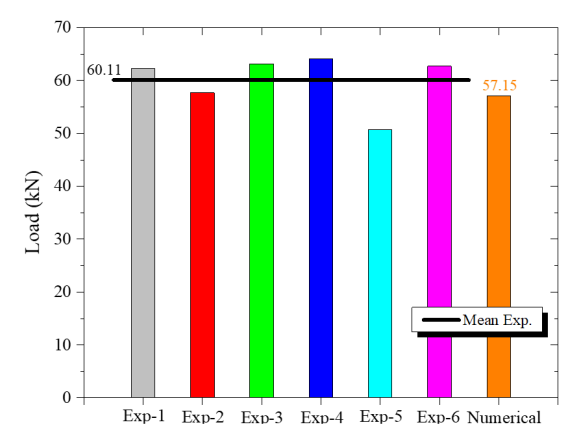

(b)

Figure 15. Validation of numerical results of the ClG30S16 series of pull-out tests: (a) force vs displacement diagrams and (b) mean maximum load.

The numerical behavior for the ClG14S12, ClG14S16, ClG30S12 and ClG30S16 curves were similar to the physical model. The maximum difference between experimental and numerical model was less than $6 \%$ in all series. Therefore, it can be said that the numerical pull-out model was calibrated.

Grout slippage was observed in all of the tested numerical and experimental series (see Figure 16). 


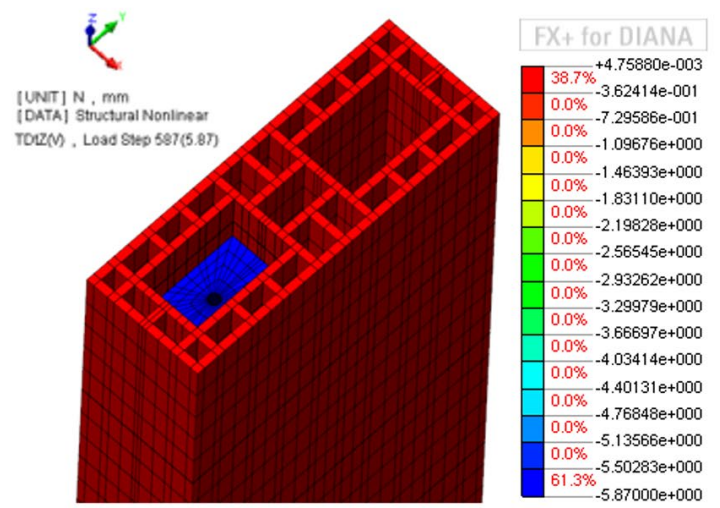

(a)

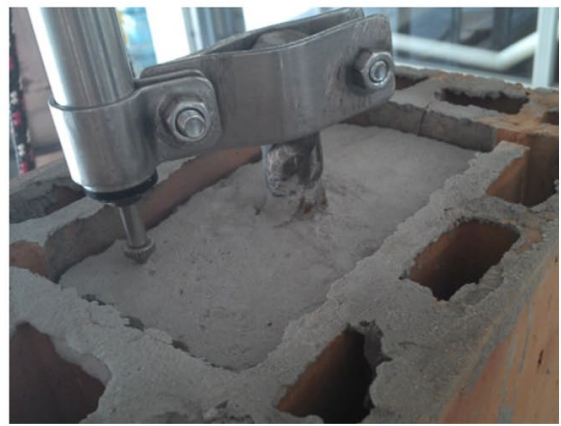

(b)

Figure 16. Displacement of the grout according to (a) the numerical model and (b) physical model of the ClG14S12 series.

\section{PARAMETRIC ANALYSIS}

After the validation of the numerical model, a parametric analysis was performed for the pull-out test varying the rebar diameters of the steel reinforcement $(8 \mathrm{~mm}, 10 \mathrm{~mm}$ and $20 \mathrm{~mm}$ ) and two types of grout (large and small compressive resistance).

Steel rebar samples of the $8 \mathrm{~mm}, 10 \mathrm{~mm}$ and $20 \mathrm{~mm}$ diameter were submitted to the direct tensile test described by Kataoka and El Debs [30] under the same test conditions of the reinforcement rebars of this study $(12.5 \mathrm{~mm}$ and $16 \mathrm{~mm})$. The yield load obtained for the $8 \mathrm{~mm}$ steel rebar was $31.01 \mathrm{kN}$, the $10 \mathrm{~mm}$ steel rebar was $44.94 \mathrm{kN}$ and the $20 \mathrm{~mm}$ steel rebar was $178.19 \mathrm{kN}$.

\subsection{Rebar Diameters of $10 \mathrm{~mm}$}

Figure 17a is the load $v s$ displacement diagram of the numerical model for the series with G14 and G30 grout and rebar diameters of $10 \mathrm{~mm}$. The experimental yield is also highlighted in the Figure 17a.

As shown in Section 2, the bond load between the grout and clay block was $11.64 \mathrm{kN}$ for G14 grout and $14.02 \mathrm{kN}$ for G30 grout, for a single grouting block (see Table 1). These loads, multiplied by the number of grouting blocks used in the pull-out specimens (4 blocks), established important limits related to the grout/block bond. The value for the G14 grout was $46.56 \mathrm{kN}$ and for the grout G30 was $56.12 \mathrm{kN}$.

Figure $17 \mathrm{~b}$ is the maximum load for these two series $(41.11 \mathrm{kN}$ and $41.26 \mathrm{kN})$ compared with the values of the load limited by bond obtained experimentally ( $46.56 \mathrm{kN}$ for G14 and $56.08 \mathrm{kN}$ for G30).

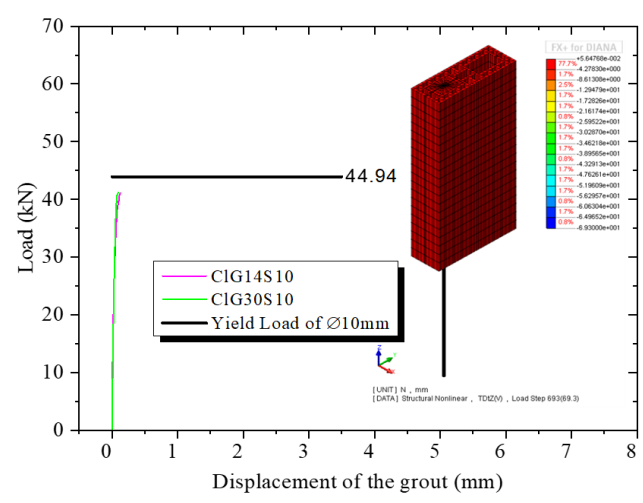

(a)

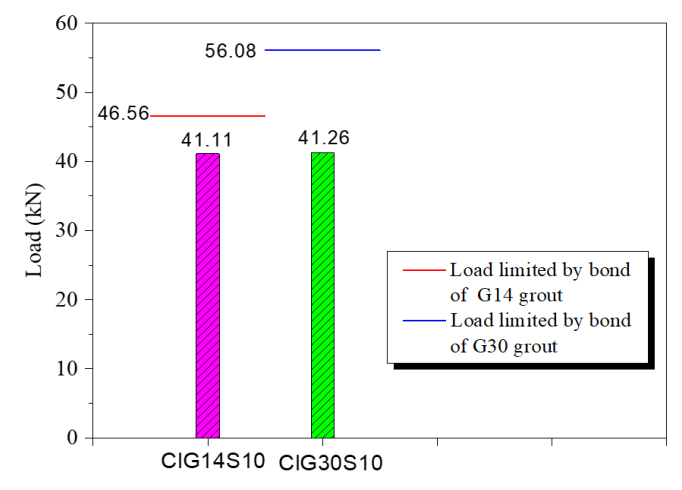

(b)

Figure 17. Pull-out tests with rebar diameters of $\varnothing 10 \mathrm{~mm}$ (a) parametric results (load vs displacement diagrams) and (b) maximum load. 
The maximum loads obtained in the numerical model was $41.11 \mathrm{kN}$ and $41.26 \mathrm{kN}$ for ClG14S10 and ClG30S10 series, respectively. These values represent a maximum difference of $9 \%$ in relation to experimental yield load of the $10 \mathrm{~mm}$ steel rebar $(44.94 \mathrm{kN})$. This difference can be considered low since simplifications and approximations are used in the numerical model. Therefore, both yield loads (experimental and numerical) were considered the same.

The numerical model stopped converging once these values were reached. Figure 17a illustrates that the grout did not slip in relation to the clay block webs for $10 \mathrm{~mm}$ of rebar diameters.

Figure $17 \mathrm{~b}$ shows that the ultimate load numerical $(41.11 \mathrm{kN}$ and $41.26 \mathrm{kN})$ was lower than the load limited by experimental bond for both grouts $(46.56 \mathrm{kN}$ and $56.08 \mathrm{kN})$, respectively. Therefore, this research concluded that the failure for pull-out specimens of $10 \mathrm{~mm}$ steel rebars was dominated by the yield load of the reinforcements and not by bond load.

The pull-out test with $8 \mathrm{~mm}$ steel rebars was not carried out numerically because the experimental yiel load for this reinforcement was $31.01 \mathrm{kN}$. This value is less than the load limited by experimental bond for both grouts $(46.56 \mathrm{kN}$ and $56.08 \mathrm{kN}$ ). For that reason, the failure will be due by the yield stress of the steel bar and not by the bond strength of the clay block/grout interface.

\subsection{Rebar Diameters of $20 \mathrm{~mm}$}

Figure 18 shows the results obtained in the parametric study using rebar diameters of $20 \mathrm{~mm}$.

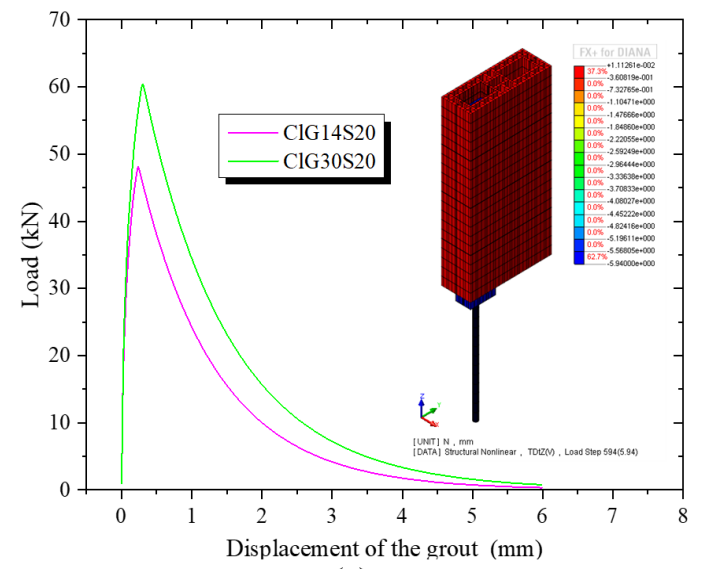

(a)

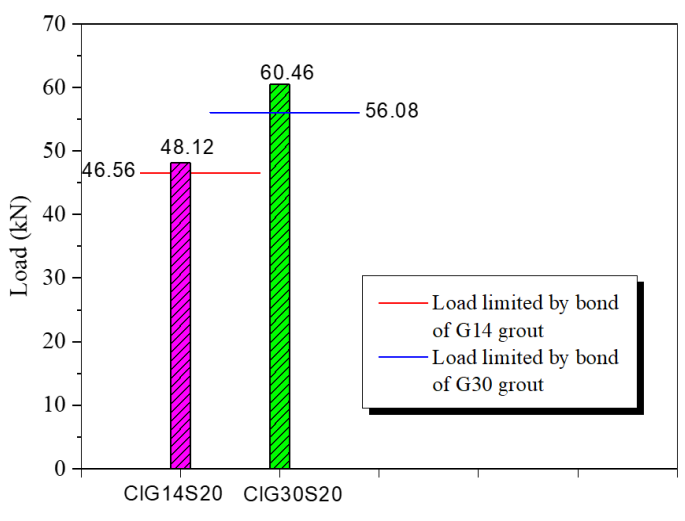

(b)

Figure 18. Pull-out tests with rebar diameters of $\varnothing 20 \mathrm{~mm}$ (a) parametric results (load vs displacement diagrams) and (b) maximum load.

The ultimate numerical load for both series $(48.12 \mathrm{kN}$ and $60.46 \mathrm{kN})$ were similar than their respective experimental load limited by bond $(46.56 \mathrm{kN}$ and $56.08 \mathrm{kN})$. The maximum difference between experimental and numerical load was of about $8 \%$. The other hand, the experimental yield load $(179.19 \mathrm{kN})$ of $20 \mathrm{~mm}$ of steel rebar diameter was significantly larger than the numerical load for both series $(48.12 \mathrm{kN}$ and $60.46 \mathrm{kN})$. Therefore, the reinforcement of $\varnothing$ $20 \mathrm{~mm}$ embedded in both series has not reached its yield limit.

Figure 18a shows that the column of the grout inside the clay blocks slipped for both grouts. Therefore, with the use of $20 \mathrm{~mm}$ diameter rebar, the effect was the same as the $12.5 \mathrm{~mm}$ and $16 \mathrm{~mm}$ reinforcement rebars, where the masonry limit state depends on the bond strength of the block/grout interface for the specific grout type.

\subsection{Comparative analysis according to Brazilian Standard Structural Masonry ABNT NBR 16868-1 [8]}

The parametric study provides a summary of the ultimate stress of the pull-out test of clay blocks based on the yield stress of the steel bar, for several reinforcement diameters, see Table 10. 
Table 10. Ultimate stress of the pull-out tests of clay blocks with respect to the yield stress of the steel rebar for different diameters.

\begin{tabular}{ccc}
\hline \multirow{2}{*}{ Rebar Diameters (mm) } & \multicolumn{2}{c}{ Ultimate Stress } \\
\cline { 2 - 3 } & G14 & G30 \\
\hline$\varnothing 8$ & $100 \% \mathrm{f}_{\mathrm{yk}}$ & $100 \% \mathrm{f}_{\mathrm{yk}}$ \\
\hline$\varnothing 10$ & $100 \% \mathrm{f}_{\mathrm{yk}}$ & $100 \% \mathrm{f}_{\mathrm{yk}}$ \\
\hline$\varnothing 12.5$ & $74 \% \mathrm{f}_{\mathrm{yk}}$ & $90 \% \mathrm{f}_{\mathrm{yk}}$ \\
\hline$\varnothing 16$ & $42 \% \mathrm{f}_{\mathrm{yk}}$ & $51 \% \mathrm{f}_{\mathrm{yk}}$ \\
\hline$\varnothing 20$ & $27 \% \mathrm{f}_{\mathrm{yk}}$ & $33 \% \mathrm{f}_{\mathrm{yk}}$ \\
\hline
\end{tabular}

As previously mentioned, the Brazilian Standard Structural Masonry ABNT NBR 16868-1 [8] imposes limits directly for the maximum tensile stress $\left(f_{s}\right)$ of the reinforcement embedded in the grout in clay blocks with smooth surfaces. These limits are:

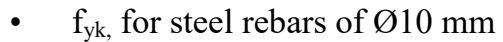

- $0.75 \mathrm{f}_{\mathrm{yk}}$, for steel rebars of $\varnothing 12.5 \mathrm{~mm}$

- $0.50 \mathrm{fyk}$, for steel rebars of $\varnothing 16 \mathrm{~mm}$ or more.

The limits obtained in this research (Table 10) are in agreement with the limits specified by the Brazilian Standard for $10 \mathrm{~mm}, 12.5 \mathrm{~mm}$ and $16 \mathrm{~mm}$ reinforcement diameter. However, the limits for $20 \mathrm{~mm}$ of diameter $\left(27 \% \mathrm{f}_{\mathrm{yk}}\right.$ and $33 \%$ $\mathrm{f}_{\mathrm{yk}}$ ) do not coincide with the limit of the Brazilian Standard ( $\left.50 \% \mathrm{f}_{\mathrm{yk}}\right)$. This research concluded that these limits reduce progressively with increasing rebar diameter. The other hand, more studies need to be done and the bond stress at the grout/block interface should be considered during the design development to guarantee safety.

\section{CONCLUSIONS}

In this paper a numerical analysis was performed to analyze the limits of the yield stress of reinforcements in clay block masonry structures. The parametric analysis was carried out by varying the rebar diameter $(8 \mathrm{~mm}, 10 \mathrm{~mm}$, and $20 \mathrm{~mm}$ ) and type of grout (large and small compressive resistance) in pull-out specimens.

The following conclusions are:

- The numerical analysis showed that the computer models of the push-out and pull-out specimens adequately represented the behavior of the physical models, and thus can be used in parametric analysis.

- The pull-out tests with rebar diameters of $8 \mathrm{~mm}$ and $10 \mathrm{~mm}$ showed that the reinforcements embedded in the grout reached their yield stress without slippage. This feature demonstrated that the anchorage length used in this work was appropriate. The grout did not slip in relation to the clay block webs.

- The pull-out tests with clay blocks, large and small compressive resistance grout and reinforcement bars with diameters of $12.5 \mathrm{~mm}, 16 \mathrm{~mm}$ and $20 \mathrm{~mm}$ showed slippage of the grout's column before the reinforcement rebars achieved their yield stresses. The failure was dominated by the lack of a sufficient bond strength of the clay block/grout interface.

- The limits achieved in this research for $8 \mathrm{~mm}, 10 \mathrm{~mm}, 12.5 \mathrm{~mm}$ and $16 \mathrm{~mm}$ diameters bars are in agreement with the limits specified by the Brazilian Standard Structural Masonry ABNT NBR 16868-1 [8]. However the limit for steel rebars with $20 \mathrm{~mm}$ of diameter was less than specified by the standard. The authors of this paper suggest $25 \% \mathrm{f}_{\mathrm{yk}}$ for $\varnothing 20 \mathrm{~mm}$ as a reference point for future investigations, while a comprehensive research program covering the bond between different clay blocks and grout infills is not performed.

- Two types of bond strengths that occur in the reinforced masonry should be considered during the design: grout/reinforcement bond and block/grout bond.

\section{ACKNOWLEDGEMENTS}

The authors would like to thank the Department of Structural Engineering of the School of Engineering of São Carlos at the University of São Paulo for permission to conduct the survey.

\section{CITATIONS}

[1] D. T. Biggs, "Grouting Masonry using Portland Cement-Lime Mortars," in Proc. Int. Build. Lime Symp., Orlando, Florida, Mar. 9-11, 2005. 
[2] V. G. Haach, G. Vasconcelos, and P. B. Lourenço, "Parametrical study of masonry walls subjected to in-plane loading through numerical modeling," Eng. Struct., vol. 33, no. 4, pp. 1377-1389, Apr 2011, http://dx.doi.org/10.1016/j.engstruct.2011.01.015.

[3] L. A. Pereira de Oliveira, "Adhesive strength as a parameter of compatibility between filler grout and structural masonry units," in 5th Int. Semin. Struct. Masonry Dev. Ctries., Florianópolis, 1994, pp. 214-227.

[4] Z. Soric and L. G. Tulin, "Bond stress/deformation in pull-out masonry specimens," J. Struct. Eng., vol. 115, no. 10, pp. 2588-2602, Oct 1889, http://dx.doi.org/10.1061/(ASCE)0733-9445(1989)115:10(2588).

[5] British Standard Institution, Code of Practice for Use of Masonry - Structural Use of Reinforced and Prestressed Masonry, BSI 5628-2, 1995.

[6] European Standard. Eurocode 6: Design of Masonry Structures, EN 1996-1-1, 2005.

[7] Standards Association of Australia, The Autralian Masonry Code, AS3700, 2001.

[8] Associação Brasileira de Normas Técnicas, Structural Masonry - Part 1: Design, NBR 16868-1, 2020 (in Portuguese).

[9] G. Sipp, "Evaluation of the bonding behavior between ceramic blocks and grouts," M.S. thesis, Fed. Univ. São Carlos, São Carlos, 2019 (in Portuguese). [Online]. Available: https://repositorio.ufscar.br/handle/ufscar/11749? show=full

[10] L. O. Guarnieri, "Influence of grout adhesion/structural clay block on the mechanical strength of the set," M.S. thesis, Mining, Metal. Mater. Eng., Fed. Univ. Rio Grande do Sul, Porto Alegre, 2017 (in Portuguese). [Online]. Available: https://lume.ufrgs.br/handle/10183/178445

[11] O. S. Izquierdo, M. R. S. Corrêa, and I. I. Soto, "Study of the block/grout interface in concrete and clay block masonry structures," IBRACON Struct. Mater. J., vol. 10, no. 4, pp. 924-936, Aug 2017, http://dx.doi.org/10.1590/s1983-41952017000400009.

[12] Associação Brasileira de Normas Técnicas, Metallic Materials - Tensile Testing Part 1: Method of Test at Room Temperature, NBR 6892-1, 2013 (in Portuguese).

[13] TNO DIANA, DIANA Finite Element Analysis - User's Manual Release 9.6. Delft, Netherland, 2015. Accessed: June 7, 2020. [Online]. Available: http://tnodiana.com

[14] L. M. F. Oliveira and M. R. S. Corrêa, "Numerical and experimental analysis of the shear capacity of interconnected concrete block walls," Ambient. Constr., vol. 17, no. 3, pp. 25-37, Jul/Sep 2017, http://dx.doi.org/10.1590/s1678-86212017000300160.

[15] N. Kumar and M. Barbato, "New constitutive model for interface elements in finite-element modeling of masonry," J. Eng. Mech., vol. 145, no. 5, 04019022, Feb 2019, http://dx.doi.org/10.1061/(ASCE)EM.1943-7889.0001592.

[16] V. G. Haach, "Development of a design method for reinforced masonry subjected to in-plane loading based on experimental and numerical analysis,” Ph.D. dissertation, Univ. Minho, Guimaraes, Portugal, 2009. [Online]. Available: www.civil.uminho.pt/masonry

[17] O. S. Izquierdo, "Study of the block/grout interface in concrete and clay block masonry structures," Ph.D. dissertation, São Carlos Sch., Eng., Univ. São Paulo, São Carlos, 2015 (in Portuguese). [Online]. Available: https://www.teses.usp.br/teses/disponiveis/18/18134/tde-13052015-165029/pt-br.php

[18] Fédération International Du Béton, Bond of Reinforcement in Concrete (Bulletin 14). Lausanne: FIB, 2002.

[19] V. G. Haach, M. A. Ramalho, and M. R. S. Corrêa, "Parametrical study of unreinforced flanged masonry walls subjected to horizontal loading through numerical modeling," Eng. Struct., vol. 56, pp. 207-217, Nov 2013, http://dx.doi.org/10.1016/j.engstruct.2013.05.009.

[20] H. J. Diógenes, "Interface parameters calibration of numerical push-out models applied to connections for adherence," Cad. Eng. Estrut., vol. 17, no. 67, pp. 37-52, 2017. Accessed: June 7, 2020. [Online]. Available: http://cadernos.set.eesc.usp.br/article/view/275/pdf_2

[21] I. S. Izquierdo, O. S. Izquierdo, M. A. Ramalho, and A. Taliercio, "Sisal fiber reinforced hollow concrete blocks for structural applications: testing and modeling," Constr. Build. Mater., vol. 151, no. 1, pp. 98-112, 2017, http://dx.doi.org/10.1016/j.conbuildmat.2017.06.072.

[22] P. B. Lourenço and J. G. Rots, "Multisurface interface model for analysis of masonry structures," J. Eng. Mech., vol. 123, no. 7, pp. 660-668, Jul 1997, http://dx.doi.org/10.1061/(ASCE)0733-9399(1997)123:7(660).

[23] G. P. A. G. Van Zijl, "Modeling masonry shear-compression: role of dilatancy highlighted," J. Eng. Mech., vol. 130, no. 11, pp. 1289-1296, Oct 2004, http://dx.doi.org/10.1061/(ASCE)0733-9399(2004)130:11(1289).

[24] P. B. Lourenço, "Masonry modeling," in Encyclopedia of Earthquake Engineering, M. Beer, I. A. Kougioumtzoglou, E. Patelli and S. K. Au, Eds., Berlin: Springer, 2015. http://dx.doi.org/10.1007/978-3-642-35344-4_153.

[25] A. H. Al-Zuhairi and A. R. Ahmed, "Behavior of clay masonry prism under vertical load using detailed micro-modeling approach," $J$. Assoc. Arab Univ. Basic Appl. Sci., vol. 26, no. 1, pp. 67-73, Mar 2019, http://dx.doi.org/10.33261/jaaru.2019.26.1.009.

[26] L. M. F. Oliveira, "Numerical and experimental study of the behaviour of vertical interfaces of interconnected structural masonry walls," Ph.D. dissertation, São Carlos Sch. Eng., Univ. São Paulo, São Carlos, 2014 (in Portuguese). [Online]. Available: https://teses.usp.br/teses/disponiveis/18/18134/tde-30072014-085747/es.php 
[27] V. Capuzzo No., M. R. S. Corrêa, and M. A. Ramalho, "Proposal of a test specimen to evaluate the shear strength of vertical interfaces of running bond masonry walls," Can. J. Civ. Eng., vol. 35, no. 6, pp. 567-573, May 2008, http://dx.doi.org/10.1139/L07139.

[28] A. Rahman and T. Ueda, "Experimental investigation and numerical modeling of peak shear stress of brick masonry mortar joint under compression," J. Mater. Civ. Eng., vol. 26, no. 9, pp. 04014061-13, Sep 2014, http://dx.doi.org/10.1061/(ASCE)MT.19435533.0000958 .

[29] G. Vasconcelos, P. B. Lourenço, and V. G. Haach, "Avaliação experimental da aderência de juntas de alvenaria de blocos de betão," in An. $7^{\circ}$ Cong. Nac. Mecânica Experimental, Vila Real, Portugal, 2008. (in Portuguese).

[30] M. N. Kataoka and A. L. H. de Cresce El Debs, "Beam-column composite connections under cyclic loading: an experimental study," Mater. Struct., vol. 48, no. 4, pp. 929-946, Nov 2015, http://dx.doi.org/10.1617/s11527-013-0204-4.

Author contributions: OS: conceptualization, supervision, writing, data curation, formal analysis, methodology; MRS: funding acquisition, supervision, formal analysis, methodology, writing; II: data curation, methodology, writing; IG: formal analysis, writing.

Editors: Edgar Bacarji, Guilherme Aris Parsekian. 